\title{
PENENTU KEBERHASILAN REDENOMINASI MATA UANG: PENDEKATAN HISTORIS DAN EKSPERIMENTAL
}

\author{
Andika Pambudi', \\ Bambang Juanda ${ }^{2}$, \\ D.S. Priyarsono ${ }^{2}$
}

\begin{abstract}
Redenomination is a simplification of nominal value of currency by reducing digit (zero number) without reducing the real value of the currency. The main objective of this research was to examine whether the economic conditions at the time of redenomination may affect the success of currency redenomination. The methods used were regression analysis on historical data of 30 countries which are involved in redenominating their currencies, economic experiments with t-test, and survey of people' perspective. Based on regression analysis, inflation will decrease and economic growth will rise higher after redenomination, if previously a country have experienced high economic growth as well. Based on experimental research, when inflation was high, redenomination could increase the selling price. Otherwise, when inflation was low, redenomination could decrease the selling price. Changes in selling price after redenomination was not affected significantly by differences in economic growth conditions. In different economic conditions, redenomination policy did not significantly affect the changes number of transactions and total value of transactions in the market. From the survey results, public did not believe government can control inflation after redenomination. Redenomination also will not affect consumption pattern.
\end{abstract}

Keywords: Redenomination, Inflation, Economic Growth, Experiment

JEL Classification: C91, E31, E42, E58,

Peneliti di Center for Public Policy Transformation (www.transformasi.org).

2 Departemen IImu Ekonomi, Fakultas Ekonomi dan Manajemen IPB - Penulis Korespondensi (bbjuanda@yahoo.com). 


\section{PENDAHULUAN}

Redenominasi adalah penyederhanaan nilai nominal mata uang dengan mengurangi digit (angka nol) tanpa mengurangi nilai riil mata uang tersebut. Bank Indonesia (BI) telah merencanakan redenominasi rupiah dengan menghilangkan tiga angka nol pada nilai uang, harga barang, maupun upah. Nilai nominal mata uang yang terlalu besar mencerminkan bahwa di masa lalu negara pernah mengalami inflasi yang tinggi atau pernah mengalami kondisi fundamental perekonomian yang kurang baik (Kesumajaya, 2011). Bahkan jika suatu negara selalu mengalami inflasi yang tinggi tiap tahunnya, maka nilai uang terhadap barang akan semakin rendah (Amir, 2011). Sudah 55 negara yang telah melakukan redenominasi, diantaranya ada yang dianggap sukses dan gagal. Salah satu indikator keberhasilan penerapan redenominasi adalah tingkat inflasi setelah kebijakan tersebut diterapkan. Redenominasi akan dianggap gagal jika mengalami inflasi tinggi atau hiperinflasi setelah kebijakan diterapkan.

Indonesia yang saat ini berencana melakukan redenominasi telah mengalami beberapa kali guncangan dan ketidakstabilan dalam nilai mata uang maupun tingkat inflasi. Sebelum Indonesia merdeka, pada tahun 1944, nilai Rupiah memiliki nilai yang hampir seimbang dengan dollar AS, yaitu Rp 1,88 per dollar AS. Lalu, pada 7 Maret 1946 nilai Rupiah pertama kali menurun sebesar 30 persen menjadi Rp 2,65 per dollar AS. Tahun 1950 pemerintah melakukan sanering dari pecahan Rp5 ke atas, sehingga nilainya menjadi setengah dari nilai semula. Kemudian sanering kedua berlanjut pada tahun 25 Agustus 1959 pemerintah kembali melakukan pemangkasan nilai Rupiah.

Tingkat inflasi yang tinggi akan berdampak pada pelemahan nilai mata uang. Hal ini terlihat pada tahun 1960-an Indonesia mengalami hiperinflasi yang sangat tinggi yang puncaknya yaitu tahun 1966 sebesar 1136 persen. Selanjutnya pada tahun 1971 nilai Rupiah terdepresiasi hingga mencapai Rp 415 per dollar AS (World Bank, 2012). Setelah 68 tahun merdeka, Rupiah sekarang telah berada di sekitar level Rp 9.700 per dollar AS. Karena nilai yang semakin melemah itulah menjadi salah satu alasan pemerintah ingin meningkatkan martabat Rupiah. Saat ini dianggap sebagai waktu yang tepat karena tingkat inflasi di Indonesia relatif stabil dalam beberapa tahun terakhir bahkan dapat dikatakan bertipe creeping inflation atau berada di sekitar satu digit tiap tahunnya. Inflasi yang stabil mencerminkan kestabilan harga pada beberapa barang yang membentuk tingkat harga konsumen.

Selain dampak positif dari redenominasi seperti meningkatnya kredibilitas Rupiah yang dijadikan tujuan oleh pemerintah, terdapat juga dampak negatif yang akan terjadi jika diterapkan kebijakan redenominasi. Salah satunya adalah kemungkinan masyarakat salah persepsi dengan mengira redenominasi adalah sanering. Sanering adalah kebijakan penghilangan angka nol pada mata uang, namun pemotongan tersebut tidak dilakukan pada harga-harga barang, sehingga daya beli masyarakat menurun. Pemahaman mengenai redenominasi yang salah pada masyarakat dapat menimbulkan kepanikan yang dapat membuat situasi ekonomi mengalami gejolak. Selain itu, dengan adanya redenominasi akan ada peningkatan besarnya biaya operasional perusahaan 
dan perbankan karena mengganti sistem informasi dan teknologinya yang membutuhkan waktu penyesuaian untuk menerapkan teknologi akuntansi untuk menyesuaikan dengan penyederhanaan nominal. Bank Indonesia juga akan mengeluarkan biaya yang besar untuk mencetak uang baru hasil redenominasi dan sosialisasi publik. Selain itu dampak sosial lain berupa ketidakpercayaan masyarakat terhadap Rupiah (Kesumajaya, 2011).

Berdasarkan pernyataan Wibowo (2013), dampak yang akan muncul karena perubahan nominal mata uang adalah munculnya bias psikologis yang disebut money illusion. Sebagian besar masyarakat akan mempersepsikan bahwa harga barang menjadi lebih murah karena dihilangkannya nilai nol dari mata uang terdahulu. Sebagai contoh, misalkan terjadi kenaikan harga barang sebesar Rp 7.000, hal tersebut dirasakan sangat berat oleh konsumen. Namun ketika setelah terjadi redenominasi kenaikan Rp 7 dirasakan lebih ringan oleh masyarakat. Padahal kenaikan tersebut mempunyai nilai yang sama. Konsumen kurang memperhatikan proses re-scaling dari nominal Rupiah yang lama ke nominal Rupiah yang baru. Money Illusion akan semakin memberikan efek ketika konsumen akan melihat kembali nilai riil dari barang yang telah mereka beli akibat berubahnya harga nominal secara serentak. Redenominasi mendorong perilaku konsumsi menjadi lebih besar. Harga baru yang dirasakan lebih murah karena terjadinya money illusion membuat willingness to pay (kemauan untuk membayar) dari konsumen menjadi meningkat. Melihat perubahan dari perilaku masyarakat tersebut, produsen barang akan meningkatkan harga hingga batas yang masih ditolelir oleh konsumen.

Pro dan kontra terhadap wacana kebijakan redenominasi mencerminkan suatu spekulasi publik terhadap ketidakpastian dampak yang akan terjadi jika dilakukan redenominasi pada mata uang Rupiah pada saat ini. Kajian mengenai dampak yang akan ditimbulkannya perlu dikaji secara ilmiah melalui metode percobaan. Menurut Juanda (2010) data hasil percobaan akan lebih mudah diinterpretasi dalam menyimpulkan hubungan sebab akibat dibandingkan data hasil survei atau data sekunder. Penelitian ini bertujuan untuk melihat faktor-faktor yang mempengaruhi keberhasilan redenominasi mata uang. Faktor-faktor tersebut adalah kondisi perekonomian pada saat melaksanakan kebijakan redenominasi, diantaranya tingkat inflasi dan pertumbuhan ekonomi. Adapun keberhasilan redenominasi dapat dilihat dari perubahan tingkat inflasi dan pertumbuhan ekonomi setelah kebijakan redenominasi diterapkan.

Ruang lingkup dalam penelitian ini terbagi menjadi tiga bagian. Pertama, memberikan identifikasi faktor-faktor yang mempengaruhi keberhasilan kebijakan redenominasi di suatu negara, melalui kajian data sekunder yang berasal data historis negara-negara yang telah melakukan redenominasi. Kedua, menganalisis dampak kebijakan redenominasi Rupiah terhadap perilaku pelaku ekonomi yang selanjutnya akan dikaji pengaruhnya terhadap kinerja perekonomian. Ketiga, merekam perspektif masyarakat sebagai produsen dan konsumen terhadap kebijakan redenominasi mata uang. Dalam mengkaji bagian penelitian yang kedua, data yang digunakan akan diperoleh dari data primer hasil metode percobaan (experiment). Kinerja perekonomian yang dikaji, seperti tingkat inflasi dan pertumbuhan ekonomi akan dilihat berdasarkan perubahan jumlah transaksi dan harga rata-rata setelah redenominasi yang 
dihasilkan dari respons simulasi percobaan. Redenominasi yang dimaksud dalam penelitian ini adalah kebijakan penghapusan tiga angka nol pada nilai mata uang Rupiah, unit harga, unit upah, serta segala sesuatu yang dinilai dengan nominal mata uang.

\section{TEORI}

\subsection{Keterkaitan Redenominasi dengan Kinerja Perekonomian}

Relatif belum banyak studi yang mengkaji peranan redenominasi terhadap kinerja perekonomian. Namun ada beberapa pendapat yang menyatakan bahwa keputusan suatu negara dalam melakukan kebijakan redenominasi sangat dipengaruhi oleh kondisi perekonomian sebelumnya. Selain itu, perubahan indikator-indikator ekonomi di suatu negara juga dapat dipengaruhi oleh penerapan kebijakan redenominasi mata uangnya.

Suhendra dan Handayani (2012) mengkaji keterkaitan kebijakan redenominasi dengan tingkat inflasi, nilai tukar, pertumbuhan ekonomi, dan nilai ekspor. Dengan menggunakan data indikator-indikator ekonomi dari 27 negara yang melakukan redenominasi, terlihat bahwa inflasi dan pertumbuhan ekonomi adalah variabel yang secara signifikan terpengaruh oleh redenominasi mata uang. Sementara itu, tingkat inflasi yang tinggi merupakan faktor utama (most dominant driving factor) yang mendorong suatu negara memutuskan untuk melakukan redenominasi mata uang. Temuan ini sejalan dengan apa yang dikemukakan oleh Mosley (2005) yang menyatakan inflasi saat ini dan masa lalu adalah prediktor terpenting dari dilakukan atau tidaknya redenominasi.

Iona (2005) melakukan studi mengenai manfaat jangka panjang dari redenominasi, alasan pemilihan waktu untuk implementasi redenominasi, dan pengaruhnya terhadap harga. Hasil kajian menunjukkan dampak jangka panjang dari redenominasi adalah: 1) terbangunnya kepercayaan publik terhadap mata uang domestik; 2) meningkatnya tabungan dalam mata uang domestik; serta 3) uang yang disimpan di luar sistem keuangan nasional akan masuk ke dalam pasar. Redenominasi mata uang akan sukses dilakukan hanya jika memenuhi dua kondisi berikut: 1) tingkat inflasi yang rendah dengan kecenderungan yang menurun; dan 2) berhasilnya program reformasi dan restrukturisasi ekonomi, seperti pertumbuhan PDB riil yang tinggi. Jika kondisi terebut tidak terpenuhi maka redenominasi menjadi tidak berguna. Iona (2005) juga menyatakan indikator-indikator yang perlu dimonitor untuk menilai dampak redenominasi yaitu Indeks Harga Konsumen, daya beli, nilai tukar, rata-rata deposito 1-bulan, Indeks Kepercayaan Konsumen, dan Indeks Kepercayaan Bisnis.

\subsection{Keterkaitan Redenominasi dengan Perilaku Pelaku Ekonomi}

Dampak dapat terjadi dalam penerapan redenominasi adalah munculnya bias psikologis yang disebut money illusion (Wibowo, 2013). Ilusi ini dapat muncul karena perubahan nominal 
harga barang akibat redenominasi. Sebagian besar masyarakat akan mempersepsikan bahwa harga barang menjadi lebih murah karena dihilangkannya nilai nol dari mata uang terdahulu. Hobijn et al (2006) juga menunjukkan bahwa telah terjadi money illusion yang di negara Eropa yang telah melakukan perubahan mata uang menjadi Euro. Euro yang nominalnya lebih sedikit dibandingkan mata uang sebelumnya dirasakan lebih murah oleh masyarakat. Hobijn et al (2006) berpendapat peningkatan harga setelah redenominasi dapat dijelaskan dangan model umum dari biaya harga menu, dengan memasukkan keputusan perusahaan ketika mereka mengadopsi mata uang yang baru.

Selanjutnya konsumen akan mengevaluasi kembali manajemen strategi uang mereka untuk beradaptasi dengan mata uang baru terutama ketika diperkenalkan mata uang yang baru khususnya ketika mata uang yang baru dan mata uang yang lama dipergunakan secara bersama-sama, menunggu waktu untuk menghilangkan mata uang yang lama. Marques dan Dehaene (2004) mengemukakan bahwa terdapat dua proses utama yang dapat terjadi ketika sebuah negara mengadaptasi mata uang yang baru : rescaling (mengubah semua harga pada mata uang lama ke nilai pada mata uang yang baru pada waktu yang sama) atau re-learning (mengingat harga yang baru dari barang konsumen secara satu persatu). Proses pertama diprediksikan akan mengalami penyesuaian yang mudah pada mata uang yang baru, sementara proses kedua akan mengalami penyesuaian yang lebih lama dan rumit.

Sementara itu Money/Euro Illusion memperlihatkan persepsi harga dalam denominasi baru yang lebih kecil dan mata uang yang lebih rendah daripada ketika dinyatakan dalam bentuk mata uang yang lama jika memiliki nilai nominal yang lebih tinggi. (Gamble et al. 2002). Hal ini menunjukkan bahwa individu menyesuaikan diri dengan mata uang baru dengan nilai nominal yang lebih kecil, setidaknya, mereka mengalami kesulitan dalam memahami nilai sebenarnya dari barang dan jasa. Efek money Illusion pun dapat terjadi pada barang-barang yang harganya murah atau kenaikan harganya hanya beberapa koin sen saja. Apabila ketersediaan koin sen tidak dicukupi oleh pemerintah, konsumen akan cenderung membiarkan kenaikan harga tersebut tanpa menuntut adanya uang kembalian dari penjual, hal tersebut disebut trivialization.

Kasus trivalization dapat dilihat pada Ghana dimana tingkat inflasinya meningkat sebesar lima persen satu tahun setelah redenominasi. Salah satu faktor penyebab kegagalan redenominasi di Ghana adalah 70 persen uang beredar yang di Ghana berada di luar sistem perbankan.Transaksi tunai di Ghana lebih dominan dibandingkan dengan transaksi melalui perbankan. Kondisi ini diperparah oleh pemerintah yang belum juga dapat mengganti mata uang yang baru dengan mata uang yang lama setelah dua tahun redenominasi. Mehdi dan Reza (2012) juga mengungkapkan bahwa pengurangan nilai nominal mata uang akan mempunyai pengaruh secara psikologi dan sosial. Ketika mata uang memiliki nilai nominal yang rendah, maka masyarakat akan merasa mata uang tersebut bernilai kuat.

Lianto dan Suryaputra (2012) melakukan penelitian untuk mengetahui dampak dari implementasi redenominasi di Indonesia berdasarkan perspektif masyarakat Indonesia. Dari data 
yang diperoleh dengan metode survei sebanyak 100 orang yang paham akan redenominasi dan dianalisis menggunakan Structural Equation Modelling, terlihat bahwa dampak terbesar dari redenominasi adalah dapat meningkatkan kredibilitas Indonesia di mata negara lain. Temuan lainnya adalah masyarakat Indonesia menganggap redenominasi akan dapat menguntungkan mereka. Jika redenominasi sukses diimplementasikan, mata uang Rupiah akan menjadi semakin kuat dan menambah kepercayaan diri masyarakat terhadap mata uangnya.

\subsection{Percobaan dalam Kajian Kebijakan Ekonomi}

Selain untuk pengujian teori-teori ekonomi, percobaan ekonomi juga dapat digunakan untuk pengkajian suatu kebijakan ekonomi. Salah satu ilustrasinya adalah studi yang dilakukan oleh Juanda et al (2011) dalam mengkaji dan membandingkan dampak sistemik yang ditimbulkan dari kebijakan penyelamatan Bank Century dan kebijakan menutup Bank Century oleh pemerintah. Hasil penelitian menunjukkan bahwa penutupan Bank Century menyebabkan dampak sistemik yang relatif sangat rendah. Pengaruh sistemik yang cukup besar akan ditimbulkan jika penutupan bank bermasalah pada saat krisis tersebut dilakukan pada bank bermasalah yang berukuran besar. Dalam kondisi normal (tidak adanya gejolak krisis), penutupan bank bermasalah berukuran kecil seperti Bank Century tidak akan menimbulkan dampak sistemik. Tekanan dan potensi kegagalan bank sangat rendah karena stabilitas ekonomi dalam kondisi normal masih terjaga sehingga kepercayaan nasabah terhadap perbankan tidak mengalami penurunan.

Penelitian lainnya dalam mengkaji suatu kebijakan dengan metode percobaan adalah kajian tingkat kepatuhan pajak dalam sistem pemungutan pajak self assessment yang diberlakukan di Indonesia (Juanda, 2010). Penelitian ini mengkaji bagaimana pengaruh peluang pemeriksaan, denda dan tingkat pendidikan terhadap kepatuhan Wajib Pajak dalam melaporkan Surat Pemberitahuan (SPT), dengan mengendalikan faktor-faktor lainnya diusahakan sama (ceteris paribus). Faktor-faktor yang mempengaruhi tingkat kepatuhan Wajib Pajak sulit dilakukan jika menggunakan rancangan survei karena adanya pengaruh lingkungan atau objek penelitian. Hasil penelitian menunjukkan makin tinggi peluang pemeriksaan pajak dan makin besar denda akan berpengaruh positif terhadap kepatuhan Wajib Pajak dalam melaksanakan kewajiban perpajakan. Selain itu, Juanda (2010) juga menyatakan tingkat kepatuhan membayar pajak untuk "pelaku eksperimen" mahasiswa Strata 1 lebih tinggi dibandingkan tingkat kepatuhan mahasiswa Pascasarjana yang memiliki pengetahuan relatif tinggi. Selanjutnya, makin tinggi penghasilan Wajib Pajak, maka tingkat kepatuhannya makin rendah. 


\section{METODOLOGI}

\subsection{Jenis dan Sumber Data}

Jenis data yang akan digunakan dalam penelitian ini adalah berupa data primer dan sekunder. Pengumpulan data primer dalam penelitian ini diperoleh melalui simulasi percobaan (experiment). Dimana data primer yang dikumpulkan merupakan gambaran respons dari para subjek penelitian (pelaku simulasi) sebagai pelaku ekonomi dalam percobaan yang dapat dilihat dari keputusan-keputusan yang dibuat oleh para pelaku percobaan. Selain itu, data primer juga diperoleh melalui survei terhadap 168 responden yang terdiri dari 86 staf pengajar IPB, 27 mahasiswa IPB, dan 55 masyarakat umum. Untuk melihat perspektif dampak kebijakan redenominasi rupiah pada perekonomian nasional. Survei ini dimaksudkan untuk mendapatkan pertimbangan (judgement), pendapat (opini), dan perspektif mengenai kebijakan redenominasi rupiah yang akan dilaksanakan oleh pemerintah.

\begin{tabular}{|c|c|c|c|}
\hline \multicolumn{4}{|c|}{$\begin{array}{c}\text { Tabel } 1 \\
\text { Negara-negara yang Telah Melakukan Redenominasi Mata Uang }\end{array}$} \\
\hline No & Negara & $\begin{array}{l}\text { Tahun dilaksanakannya } \\
\text { redenominasi mata uang }\end{array}$ & $\begin{array}{l}\text { Jumlah angka nol yang } \\
\text { dihilangkan }\end{array}$ \\
\hline 1 & Finlandia & 1963 & 2 \\
\hline 2 & Islandia & 1981 & 2 \\
\hline 3 & Israel & 1985 & 3 \\
\hline 4 & Bolivia & 1987 & 6 \\
\hline 5 & Uganda & 1987 & 2 \\
\hline 6 & Nicaragua & 1988 & 3 \\
\hline 7 & Peru & 1991 & 6 \\
\hline 8 & Argentina & 1992 & 4 \\
\hline 9 & Sudan & 1992 & 1 \\
\hline 10 & Latvia & 1993 & 2 \\
\hline 11 & Letonia & 1993 & 200 Rublu $=1$ Lats \\
\hline 12 & Macedonia & 1993 & 2 \\
\hline 13 & Meksiko & 1993 & 3 \\
\hline 14 & Moldova & 1993 & 3 \\
\hline 15 & Uruguay & 1993 & 3 \\
\hline 16 & Brazil & 1994 & 2,750 Cruzeiros Reais $=1$ Real \\
\hline 17 & Kroasia & 1994 & 3 \\
\hline 18 & Georgia & 1995 & 6 \\
\hline 19 & Polandia & 1995 & 4 \\
\hline 20 & Ukraina & 1996 & 5 \\
\hline 21 & Rusia & 1998 & 3 \\
\hline 22 & Angola & 1999 & 6 \\
\hline 23 & Bulgaria & 1999 & 3 \\
\hline 24 & Belarus & 2000 & 3 \\
\hline 25 & Romania & 2005 & 4 \\
\hline 26 & Turki & 2005 & 6 \\
\hline 27 & Azerbaijan & 2006 & 1 \\
\hline 28 & Mozambique & 2006 & 3 \\
\hline 29 & Ghana & 2007 & 4 \\
\hline 30 & Venezuela & 2008 & 3 \\
\hline
\end{tabular}

Sumber: Iona (2005) 
Sedangkan data sekunder yang digunakan dalam penelitian ini adalah data historis 30 negara yang telah melakukan redenominasi mata uangnya sejak tahun 1963 sampai 2008 yang daftarnya dapat dilihat pada Tabel 1. Data historis yang dikumpulkan mencakup beberapa indikator makroekonomi pada tahun ketika redenominasi diterapkan di negara tertentu dan satu tahun setelahnya. Adapun variabel-variabel yang digunakan antara lain tingkat inflasi, pertumbuhan ekonomi, nilai tukar mata uang, pertumbuhan jumlah uang beredar, dan bentuk pemerintahan. Data sekunder ini diperoleh dari publikasi World Bank, International Monetary Fund, dan Center for Systemic Peace. Informasi detail mengenai sumber data dari variabelvariabel yang digunakan pada model analisis dapat dilihat di bawah ini:

\begin{tabular}{l|l}
\hline \multicolumn{1}{c|}{ Indikator } & \multicolumn{1}{c}{ Sumber } \\
\hline Tingkat Inflasi (\%) & $\begin{array}{l}\text { World Bank, 2012, World Development Indicators 2012. } \\
\text { (http://data.worldbank.org/indicator/FP.CPI.TOTL.ZG) }\end{array}$ \\
$\begin{array}{l}\text { Pertumbuhan Ekonomi (\%) } \\
\text { World Bank, 2012, World Development Indicators 2012. } \\
\text { (http://data.worldbank.org/indicator/NY.GDP.MKTP.KD.ZG) }\end{array}$ \\
$\begin{array}{l}\text { Nilai Tukar Mata Uang terhadap } \\
\text { Dolar AS (\$ AS) }\end{array}$ & $\begin{array}{l}\text { World Bank, 2012, World Development Indicators 2012. } \\
\text { (http://data.worldbank.org/indicator/PA.NUS.FCRF) }\end{array}$ \\
$\begin{array}{l}\text { Pertumbuhan Jumlah } \\
\text { Uang Beredar (\%) }\end{array}$ & $\begin{array}{l}\text { World Bank, 2012, World Development Indicators 2012. } \\
\text { (http://data.worldbank.org/indicator/FM.LBL.BMNY.ZG) }\end{array}$ \\
Indeks Bentuk Pemerintahan & $\begin{array}{l}\text { The Center for Systemic Peace, 2012, Polity IV Project. } \\
\text { (http://www.systemicpeace.org/polity/polity4.htm) }\end{array}$ \\
\hline
\end{tabular}

\subsection{Model Regresi Berganda}

Metode estimasi yang digunakan untuk mengkaji faktor-faktor yang mempengaruhi keberhasilan pelaksanaan redenominasi menggunakan model regresi berganda. Varibel eksogen atau variabel bebas (independent) dalam penelitian ini adalah pertumbuhan ekonomi, tingkat inflasi, nilai tukar mata uang, jumlah uang beredar, serta bentuk pemerintahan. Sedangkan variabel yang diamati (endogen) atau variabel tak bebas (dependent) adalah keberhasilan atau kegagalan pelaksanaan redenominasi yang diukur oleh tingkat inflasi dan pertumbuhan ekonomi satu tahun setelah redenominasi diterapkan di masing-masing negara.

Dalam penelitian ini proses regresi dilakukan dengan meregresikan variabel-variabel bebas (independent) yang merupakan kinerja perekonomian suatu negara yang berpengaruh kesuksesan atau kegagalan redenominasi (variabel tak bebas/dependent). Variabel tak bebas $(Y)$ atau variabel yang dipengaruhi adalah indikator-indikator kinerja perekonomian yang mencerminkan keberhasilan pelaksanaan redenominasi, oleh karena itu variabel ini menggunakan capaian kinerja perekonomian satu tahun setelah kebijakan redenominasi 
diterapkan. Sedangkan variabel bebas $(X)$ atau variabel yang mempengaruhi adalah kinerja perekonomian suatu negara ketika kebijakan redenominasi mulai diterapkan. Model ini belum pernah digunakan pada penelitian-penelitian terdahulu terkait redenominasi mata uang. Adapun model regresi linier berganda dalam penelitian ini adalah:

$$
\begin{aligned}
& \mathrm{Y}_{\text {setelah redenoi }}=\beta_{0}+\beta_{1} \mathrm{D}_{\text {inflasi rendah-i }}+\beta_{2} \mathrm{GRO}_{\mathrm{i}}+\beta_{3} \mathrm{LnEXR}_{\mathrm{i}}+\beta_{4} \mathrm{MON}_{\mathrm{i}}+\beta_{5} \mathrm{POL}_{\mathrm{i}} \\
& +\beta_{6}\left(\mathrm{D}_{\text {inflasi rendah -i }} * \mathrm{GROt}_{\mathrm{i}}\right)+\beta_{7}\left(\mathrm{D}_{\text {inflasi rendah-i }} * \mathrm{LnEXR}_{\mathrm{i}}\right) \\
& +\beta_{8}\left(\mathrm{D}_{\text {inflasi rendah-i }} * \mathrm{MONt}_{\mathrm{i}}\right)+\beta_{9}\left(\mathrm{D}_{\text {inflasi rendah-i }} * \mathrm{POLt}_{\mathrm{i}}\right)+\varepsilon_{\mathrm{i}} \\
& \beta 0 \quad=\text { Intersep } \\
& \beta_{1}, \ldots \beta_{9} \quad=\text { Parameter } \\
& \mathrm{Y}_{\text {setelah redenoi }} \quad=\text { Indikator keberhasilan redenominasi mata uang untuk negara ke-i: } \\
& \text { a) Tingkat inflasi satu tahun setelah redenominasi (persen) } \\
& \text { b) Pertumbuhan ekonomi satu tahun setelah redenominasi (persen) } \\
& D^{\text {inflasi rendah-i }} \quad=\text { Dummy kondisi tingkat infasi rendah pada tahun diterapkan } \\
& \text { redenominasi untuk negara ke-i, dengan nilai: } \\
& 1 \text { = inflasi rendah }(<10 \%) \text { dan } 0=\text { inflasi tinggi }(\geq 10 \%) \\
& \text { GRO } \quad=\text { Pertumbuhan ekonomi tahunan pada tahun diterapkan } \\
& \text { redenominasi untuk negara ke-i (persen) } \\
& \operatorname{LnEXR}_{\mathrm{i}} \quad=\text { Logaritma natural nilai tukar mata uang terhadap dolar pada tahun } \\
& \text { diterapkan redenominasi untuk negara ke-i (\$AS/Uang Domestik) } \\
& \text { MON }_{\mathrm{i}} \quad=\text { Pertumbuhan jumlah uang beredar pada tahun diterapkan } \\
& \text { redenominasi untuk negara ke-i (persen) } \\
& \mathrm{POL}_{\mathrm{i}} \quad=\text { Indeks bentuk pemerintahan pada tahun diterapkan redenominasi } \\
& \text { untuk negara ke-i, dengan nilai } \\
& \min =-10 \text { (sangat autokratis); } \text { maks }=10 \text { (sangat demokratis) }
\end{aligned}
$$




\section{Pengujian Hipotesis Parameter Regresi}

Selanjutnya untuk melihat pengaruh peubah bebas secara parsial dapat diuji dengan menggunakan uji t. Pengujian ini akan berguna jika pada pengujian analisis ragam diperoleh kesimpulan bahwa terdapat paling sedikit satu peubah bebas yang berpengaruh terhadap peubah tak bebas. Penggunaan uji-t ini bermanfaat untuk menunjukkan peubah bebas mana yang berpengaruh terhadap peubah tak bebas. Bentuk hipotesis parsialnya dapat dituliskan sebagai berikut:

$$
\begin{aligned}
& \mathrm{H}_{0}: \beta_{\mathrm{i}}=0 \\
& \mathrm{H}_{1}: \beta_{\mathrm{i}} \neq 0 ;(\mathrm{i}=1,2,3,4)
\end{aligned}
$$

Sementara statistik ujinya dapat dirumuskan sebagai berikut:

$$
\mathrm{t}=\frac{\widehat{\beta}_{\mathrm{i}}-\beta_{\mathrm{i}}}{\mathrm{S}_{\widehat{\beta}_{\mathrm{i}}}}
$$

Hipotesis nol akan diterima bilai nilai mutlak dari nilai t lebih besar dari nilai t-tabel atau jika nilai-p lebih kecil dari taraf nyata $(\alpha)$ sebesar 10 persen maka hipotesis nol ditolak atau $\mathrm{H}_{1}$ diterima, berarti peubah bebas i berpengaruh terhadap peubah tak bebas jika faktor lainnya tetap (cateris paribus). Nilai-p adalah peluang (risiko) kesalahan dalam menyimpulkan $\mathrm{H}_{1}$.

\subsection{Rancangan Simulasi Percobaan}

Percobaan ini merupakan simulasi kegiatan perekonomian untuk melihat pengaruh atau respons dari redenominasi mata uang terhadap perubahan perilaku produsen dan konsumen. Adapun respons perubahan perilaku pelaku ekonomi dapat dilihat dari persentase perubahan harga jual setelah redenominasi sebagai proksi dari tingkat inflasi, persentase perubahan jumlah transaksi setelah redenominasi, serta persentase perubahan nilai transaksi setelah redenominasi sebagai proksi dari tingkat pertumbuhan ekonomi.

Percobaan ekonomi dalam penelitian ini melibatkan 48 orang mahasiswa S1 Fakultas Ekonomi dan Manajemen IPB sebagai pelaku percobaan (experimental subject) yang dibagi ke dalam empat kombinasi perlakuan, sehingga masing-masing kombinasi perlakuan terdiri dari 10 atau 14 orang. Pada kelompok perlakuan pertumbuhan ekonomi tinggi, lima orang bertindak sebagai penjual dan lima orang lainnya sebagai pembeli. Sedangkan pada kelompok perlakuan pertumbuhan ekonomi tinggi, jumlah pembeli dan penjual masing-masing sebanyak tujuh orang. Pemilihan responden yang berperan sebagai penjual dan pembeli dilaksanakan dengan sistem pengundian. Faktor-faktor yang akan dilihat pengaruhnya terhadap respons yang diamati, adalah:

1. Pertumbuhan ekonomi, terdiri dari dua taraf yaitu: 1) pertumbuhan ekonomi tinggi (tujuh penjual dan tujuh pembeli); dan 2) pertumbuhan ekonomi rendah (lima penjual dan lima pembeli). 
2. Tingkat inflasi, terdiri dari dua taraf yaitu: 1) inflasi tinggi (unit cost penjual besar); dan 2) inflasi rendah (unit cost penjual kecil)

Masing-masing penjual dari tiap kelompok percobaan ekonomi di atas diberikan unit cost untuk barang yang akan dijualnya. Demikian juga, masing-masing pembeli dari tiap kelompok percobaan ekonomi di atas diberikan unit value untuk barang yang akan dibelinya. Setiap pelaku percobaan yang berperan sebagai penjual menggambarkan dua produsen, sehingga menawarkan sebanyak dua buah barang. Setiap pelaku percobaan yang berperan sebagai pembeli juga menggambarkan dua konsumen, sehingga memiliki dua unit value yang berbeda. Unit value pertama dan kedua tidak dapat diakumulasi karena diasumsikan sebagai pembeli yang berbeda. Kumpulan nilai unit cost yang dipegang oleh para penjual di tiap kelompok percobaan akan membentuk suatu kurva penawaran teoritis, dan kumpulan nilai unit value yang dipegang oleh para pembeli di tiap kelompok percobaan akan membentuk suatu kurva permintaan teoritis.

\begin{tabular}{l|l|l}
\multicolumn{2}{c}{ Penjabaran Kondisi Perlakuan dalam Simulasi Percobaan } \\
\hline \multirow{2}{*}{ Pertumbuhan Ekonomi } & Tinggi & $\begin{array}{l}\text { Pada simulasi percobaan ditentukan } \\
\text { bahwa jumlah pelaku ekonomi berjumlah } \\
14 \text { orang yang terdiri dari 7 penjual dan 7 } \\
\text { pembeli }\end{array}$ \\
\cline { 2 - 3 } & Rendah & $\begin{array}{l}\text { Pada simulasi percobaan ditentukan } \\
\text { bahwa jumlah pelaku ekonomi berjumlah } \\
10 \text { orang yang terdiri dari 5 penjual dan 5 } \\
\text { pembeli }\end{array}$ \\
\hline \multirow{2}{*}{ Tingkat Inflasi } & Tinggi & $\begin{array}{l}\text { Inflasi yang tinggi ini digambarkan dengan } \\
\text { unit cost yang lebih tinggi dibandingkan } \\
\text { kelompok perlakuan inflasi rendah }\end{array}$ \\
\hline & Rendah & $\begin{array}{l}\text { Inflasi yang tinggi ini digambarkan dengan } \\
\text { unit cost yang lebih rendah dibandingkan } \\
\text { kelompok perlakuan inflasi tinggi }\end{array}$ \\
\cline { 2 - 3 } & \multicolumn{2}{l}{} \\
\hline
\end{tabular}

Berdasarkan respons yang akan diamati, instruksi percobaan dalam penelitian ini merujuk kepada penelitian Juanda (2000) yaitu berbentuk transaksi jual beli barang yang bersifat inelastis terhadap harga, dengan sistem pasar Posted Offer. Sistem pasar Posted Offer adalah sistem pasar yang tidak ada tawar-menawar harga dalam transaksi jual beli, contoh nyatanya seperti transaksi di retail-retail supermarket atau swalayan. Simulasi percobaan ekonomi ini berdasarkan kepada induced value theory, dimana dengan penggunaan insentif/imbalan yang tepat dan nyata akan memungkinkan pelaku percobaan dapat memunculkan (induced) karakteristik tertentu sesuai dengan tujuan percobaan. Oleh karena itu data yang diperoleh dari hasil percobaan berasal dari kondisi yang sudah terkontrol/terkendali atau sudah tidak terpengaruh oleh faktor-faktor 
lain, sehingga data tersebut akan menjadi lebih baik dalam mengkaji dampak suatu kebijakan terhadap perilaku pelaku ekonomi dibandingkan data dari survei (Juanda, 2012).

Prosedur percobaan secara umum adalah sebagai berikut:

1. Peserta percobaan diacak oleh peneliti untuk menjadi lima orang pembeli dan lima orang penjual (kondisi pertumbuhan ekonomi rendah) atau tujuh orang pembeli dan tujuh orang penjual (kondisi pertumbuhan ekonomi tinggi).

2. Peserta percobaan terlebih dahulu membaca dan memahami instruksi percobaan sesuai dengan peranannya masing-masing. Peneliti menjelaskan instruksi secara rinci untuk membantu peserta percobaan yang masih kurang jelas terhadap instruksi yang diberikan.

3. Peserta diberikan lembar keputusan sesuai dengan peranannya masing-masing. Setiap peserta diharuskan mencatat setiap transaksi yang dilakukan selama percobaan pada lembar keputusannya setiap ulangan.

4. Pembeli dan penjual mendapatkan unit value dan unit cost masing-masing.

5. Pada ulangan pertama pembeli akan dipisahkan dengan penjual dimana pembeli akan meninggalkan ruangan. Penjual harus menentukan harga jualnya diatas unit costnya untuk kondisi sebelum redenominasi, setelah itu penjual langsung menentukan harga jual untuk kondisi setelah redenominasi dimana harga jualnya boleh tetap, lebih, atau kurang dari harga sebelum redenominasi.

6. Pembeli diundi urutan pembeliannya untuk kemudian mereka masuk satu per satu ke ruangan penjual untuk membeli barang. Pembeli harus membeli barang dengan harga di bawah unit value.

7. Masing-masing pembeli dan penjual harus mencatat hasil transaksinya pada lembar keputusan yang telah disediakan.

8. Masing-masing peserta percobaan melakukan prosedur yang sama setiap ulangannya, namun kondisi awal ditentukan secara acak oleh peneliti di awal ulangan.

9. Pada akhir percobaan (ulangan), peserta mengumpulkan lembar keputusan kepada peneliti.

10. Keuntungan yang diperoleh masing-masing peserta percobaan dihitung sesuai dengan transaksi yang terlampir pada lembar keputusan peserta percobaan.

\subsection{Uji Beda Nilai Tengah Dua Populasi Bebas}

Data primer yang dihasilkan melalui rancangan percobaan ekonomi akan dianalisis dengan menggunakan uji beda nilai tengah dua populasi saling bebas. Dimana dua populasi yang dimaksud adalah dua kelompok kombinasi perlakuan atau kondisi perekonomian yang 
berbeda-beda. Dua kelompok dikatakan saling bebas jika pemilihan unit-unit contoh pertama tidak tergantung pada bagaimana unit-unit contoh kedua dipilih dan sebaliknya (Matjik dan Sumertajaya, 2002). Sebelum membandingkan dua populasi, terlebih dahulu diperhatikan kondisi keragaman data dari populasi-populasi yang akan dibandingkan.

Menurut Matjik dan Sumertajaya (2002), kondisi keragaman data dua populasi dapat dibedakan menjadi dua, yaitu keragaman sama (homogen) atau $\sigma_{1}{ }^{2}=\sigma_{2}{ }^{2}=\sigma^{2}$ dan keragaman tidak sama (heterogen) atau $\sigma_{1}^{2} \neq \sigma_{2}^{2} \neq \sigma^{2}$. Kedua kondisi tersebut akan sangat menentukan akurasi kesimpulan yang diperoleh. Oleh karena itu, diperlukan metode pengujian yang tepat untuk setiap kondisi. Adapun bentuk hipotesis untuk kedua kondisi tersebut sama, yaitu:

$$
\begin{aligned}
& \mathrm{H}_{0}: \mu_{1}-\mu_{2} \geq 0 \\
& \mathrm{H}_{1}: \mu_{1}-\mu_{2}<0 ; \text { atau } \\
& \mathrm{H}_{0}: \mu_{1}-\mu_{2} \leq 0 \\
& \mathrm{H}_{1}: \mu_{1}-\mu_{2}>0
\end{aligned}
$$

Walaupun bentuk hipotesis untuk kedua kondisi keragaman sama, namun galat baku yang digunakan dalam perhitungan statistik uji berbeda. Hal ini dapat ditunjukkan sebagai berikut:

Bila terbukti ragam sama $\left(\sigma_{1}^{2}=\sigma_{2}^{2}=\sigma^{2}\right)$ maka statistik ujinya adalah:

$$
\begin{aligned}
& T_{\text {hitung (ragam sama) }}=\frac{\left(\bar{X}_{1}-\bar{X}_{2}\right)-\left(\mu_{1}-\mu_{2}\right)}{S_{g} \sqrt{\left(\frac{1}{n_{1}}\right)+\left(\frac{1}{n_{2}}\right)}} \\
& \text { dimana } S_{g}=\sqrt{\frac{\left(n_{1}-1\right) s_{1}^{2}+\left(n_{2}-1\right) s_{2}^{2}}{n_{1}+n_{2}-2}}
\end{aligned}
$$

Dengan derajat bebas sebesar $n_{1}+n_{2}-2$. Dalam hal ini $S_{g}$ dinyatakan sebagai ragam gabungan dari ragam contoh 1 dengan ragam contoh 2 . Sedangkan bila ragamnya tidak sama $\left(\sigma_{1}^{2} \neq \sigma_{2}^{2} \neq \sigma^{2}\right)$ maka statistik ujinya adalah sebagai berikut:

$$
\mathrm{T}_{\text {hitung (ragam tidak sama) }}=\frac{\left(\overline{\mathrm{X}}_{1}-\overline{\mathrm{X}}_{2}\right)-\left(\mu_{1}-\mu_{2}\right)}{\sqrt{\left(\frac{s_{1}^{2}}{n_{1}}\right)+\left(\frac{s_{2}^{2}}{n_{2}}\right)}}
$$




$$
\begin{aligned}
& \text { dimana, } \\
& \bar{X}_{1} \quad=\text { nilai tengah unit-unit contoh pertama } \\
& \bar{X}_{2}=\text { nilai tengah unit-unit contoh kedua } \\
& \mu_{1} \quad=\text { nilai tengah populasi pertama } \\
& \mu_{2} \quad=\text { nilai tengah populasi kedua } \\
& \mathrm{S}^{2}{ }_{1} \quad=\text { ragam contoh pertama } \\
& \mathrm{s}^{2}{ }_{2}=\text { ragam contoh kedua } \\
& \mathrm{n}_{1}=\text { jumlah unit contoh pertama } \\
& \mathrm{n}_{2}=\text { jumlah unit contoh kedua }
\end{aligned}
$$

Untuk menetapkan daerah kritis dalam rangka menolak hipotesis nol (critical region to reject $/ \mathrm{H}_{0}$ ) sangat tergantung pada tiga hal yaitu bentuk hipotesis tandingan $\left(\mathrm{H}_{1}\right)$, statistik uji yang digunakan, dan besarnya taraf nyata pengujian $(\alpha)$. Arah penolakan hipotesis nol searah dengan hipotesis tandingan, yaitu:

- Jika $\mathrm{H}_{1}: \mu_{1}-\mu_{2}<0$ maka daerah kritisnya $T_{\text {hitung }}<-\mathrm{T}_{\text {, db }}$

- Jika $\mathrm{H}_{1}: \mu 1-\mu_{2}>0$ maka daerah kritisnya $T_{\text {hitung }}>T^{\alpha} \alpha_{\text {, db }}$

Selain menggunakan $\mathrm{T}_{\text {hitung }}$ kaidah dalam memutuskan perbedaannya signifikan atau tidak pada kondisi yang diperbandingkan adalah apabila nilai probabilitasnya ( $p$-value) lebih kecil daripada level signifikansi atau taraf nyata sebesar sepuluh persen $(\alpha=0.1)$. Jika demikian, maka antara dua kondisi yang berbeda tersebut perbedaan nilai respons yang diamati signifikan atau berbeda nyata.

\section{HASIL DAN ANALISIS}

\subsection{Faktor-faktor yang Mempengaruhi Keberhasilan Redenominasi Mata Uang Pendekatan Data Historis 30 Negara}

Berdasarkan hipotesis yang disusun oleh Mosley (2005) disebutkan bahwa yang menjadi alasan dilakukannya redenominasi mata uang di suatu negara adalah 1) menghentikan atau mengurangi tingkat inflasi yang tinggi; 2) stabilisasi perekonomian; serta 3) meningkatkan kredibilitas mata uang. Suatu negara dikatakan berhasil jika tujuan-tujuan dari dilakukan redenominasi tercapai oleh negara tersebut, seperti tingkat inflasi yang rendah, pertumbuhan ekonomi yang tinggi, dan nilai tukar mata uang yang kuat. Oleh karena itu dalam penelitian ini dilakukan kajian terhadap variabel-variabel ekonomi tersebut setelah redenominasi dilaksanakan di suatu negara. Kajian tersebut dengan melakukan analisis regresi berganda terhadap variabel- 
redenominasi $\left(D_{\text {inflasirendah-t }}\right)$ memiliki nilai koefisien sebesar $-12,1$. Hal ini berarti bahwa negara yang sedang mengalami inflasi rendah saat redenominasi dilakukan $(<10 \%)$ cenderung memiliki tingkat inflasi satu tahun setelahnya lebih rendah daripada negara yang mengalami inflasi tinggi ( $\geq 10 \%$ ), dengan rata-rata perbedaannya sebesar 12,1 persen, cateris paribus. Namun demikian hasil ini mempunyai resiko kesalahan 98,9 persen sehingga dapat dikatakan tidak ada perbedaan yang signifikan antara dua kondisi tingkat inflasi yang berbeda.

Nilai koefisien variabel dummy untuk tingkat inflasi rendah yang negatif ini, sejalan dengan teori yang menyatakan bahwa tingkat inflasi yang rendah menyebabkan ekspektasi masyarakat terhadap kenaikan harga-harga barang pada masa yang akan datang menjadi rendah (Blanchard, 2006). Masyarakat membentuk ekspektasi terhadap inflasi tersebut berdasarkan inflasi yang sedang diamati atau tahun sebelumnya $\left(\pi_{t}{ }_{t}=\pi_{t-1}\right)$, yang disebut oleh Mankiw (2003) dengan istilah ekspektasi adaptif (adaptive expectations). Inflasi masa lalu mempengaruhi ekspektasi inflasi masa depan, Solow dalam Mankiw (2003) menyatakan bahwa "Kita mengalami inflasi karena kita mengharapkan inflasi, dan kita mengharapkan inflasi karena kita mengalaminya". Dengan kata lain, kenaikan inflasi masa lalu mempengaruhi kenaikan eskpektasi inflasi yang akhirnya dapat menyebabkan kenaikan inflasi aktual pada tahun berikutnya.

Pada negara-negara yang sedang menerapkan redenominasi bahkan cenderung mengalami money illusion dimana masyarakatnya membuat kesalahan dalam menilai perubahan nominal atau riil. Kebijakan perubahan nilai nominal pada mata uang dan disertai dengan inflasi yang tinggi akan mempersulit masyarakat untuk membandingkan nilai riil sebelum dan setelah kebijakan. Blanchard (2006) juga mengkategorikan money illusion ini sebagai biaya dari inflasi. Oleh karena itu jika ada kebijakan yang mengubah nilai nominal mata uang ketika inflasi tinggi, hal ini dapat dimanfaatkan oleh penjual untuk meningkatkan harga jual karena ekspektasi masyarakat terhadap inflasi sudah tinggi akibat tingkat inflasi yang sedang terjadi serta kenaikan harga-harga tersebut akan tersilamkan oleh money illusion yang ditimbulkan akibat redenominasi mata uang.

Variabel yang signifikan mempengaruhi tingkat inflasi satu tahun setelah redenominasi dengan nilai probabilitas dibawah taraf nyata $10 \%$ adalah pertumbuhan ekonomi pada tahun diterapkan redenominasi (GRO) dan pertumbuhan jumlah uang beredar pada tahun diterapkan redenominasi (MON). Semakin baik pertumbuhan ekonomi pada saat dilakukan redenominasi, maka tingkat inflasi satu tahun setelahnya akan cenderung menurun. Sementara koefisien MON bernilai positif menunjukkan bahwa semakin banyak jumlah uang beredar, maka setelah redenominasi tingkat inflasi cenderung meningkat. Sedangkan, variabel lainnya di dalam model seperti interaksi dummy kondisi tingkat inflasi pada saat redenominasi dengan variabel lain tidak memiliki pengaruh yang signifikan. Hasil analisis ini dapat menjelaskan kenapa ada negara yang meraih tingkat inflasi yang rendah dan stabil setelah diterapkan redenominasi mata uang dan ada negara yang mencapai hasil sebaliknya. Peranan kondisi perekonomian pada saat dilakukannya kebijakan redenominasi menjadi hal penting untuk diperhatikan karena dapat mempengaruhi kondisi perekonomian setelah kebijakan diterapkan. 


\subsubsection{Pertumbuhan Ekonomi Satu Tahun Setelah Redenominasi}

Model regresi untuk tingkat pertumbuhan ekonomi satu tahun setelah redenominasi mempunyai nilai $\mathrm{R}^{2}$ sebesar 40,4 persen, artinya bahwa keragaman total dalam data diterangkan sebesar 40,4 persen sedangkan sisanya diterangkan oleh faktor-faktor lain di luar model. Uji F statistik pada model ini dilihat dari Prob (F-stat) sebesar 0,083, yang berarti empat variabel independen secara bersama-sama berpengaruh secara signifikan terhadap pertumbuhan ekonomi satu tahun setelah redenominasi pada tingkat kepercayaan 10 persen.

Pada model regresi pertumbuhan ekonomi satu tahun setelah redenominasi, variabel dummy tingkat inflasi pada tahun dilaksanakan redenominasi $\left(\mathrm{D}_{\text {inflasirendah }}\right)$ memiliki nilai koefisien sebesar 3,62. Hal ini berarti negara yang mengalami inflasi rendah ketika redenominasi diterapkan cenderung memiliki pertumbuhan ekonomi yang lebih tinggi setelah redenominasi daripada negara mengalami inflasi tinggi. Namun dalam model ini variabel $D_{\text {inflasirendah }}$ juga tidak signfikan karena memiliki resiko kesalahan 86.4 persen atau diatas taraf nyata 10 persen. Variabel yang signifikan mempengaruhi pertumbuhan ekonomi satu tahun setelah redenominasi hanyalah pertumbuhan ekonomi pada saat redenominasi diterapkan. Semakin tinggi pertumbuhan ekonomi suatu negara ketika menerapkan redenominasi, maka satu tahun setelahnya pertumbuhan ekonomi akan cenderung meningkat. Sementara variabel lainnya tidak signifikan mempengaruhi pertumbuhan ekonomi satu tahun setelah redenominasi. Hasil ini kembali menyajikan bahwa ekspektasi berperan penting dalam menentukan capaian kondisi perekonomian suatu negara, khususnya pada 30 negara yang telah melakukan redenominasi.

\subsection{Hasil Simulasi Percobaan Sistem Transaksi Pasar Posted Offer}

Arah sebab-akibat antara kebijakan redenominasi mata uang dan kondisi perekonomian sulit untuk ditetapkan, salah satu cara untuk menentukannya adalah dengan melakukan eksperimen atau percobaan terkontrol. Percobaan dilakukan untuk melihat respons kebijakan redenominasi yaitu penghilangan tiga angka nol pada nilai nominal mata uang rupiah terhadap harga jual, jumlah transaksi, dan total nilai transaksi di pasar komoditas beras dengan sistem jual-beli posted offer. Dari respons hasil percobaan tersebut juga membandingkan perbedaan pengaruh redenominasi pada beberapa kondisi perekonomian yang berbeda, seperti kondisi inflasi dan pertumbuhan ekonomi. Simulasi percobaan ini dilakukan dengan prosedur simulasi yang sudah dijelaskan sebelumnya pada bagian metodologi.

\subsubsection{Implikasi Kebijakan Redenominasi terhadap Perubahan Harga Jual pada Sistem Pasar Posted Offer}

Berdasarkan pengalaman negara-negara lain yang telah melakukan redenominasi mata uang, terdapat dua kemungkinan yang akan terjadi setelah kebijakan ini diterapkan yaitu 
pertama harga-harga barang terkendali dan stabil, lalu kemungkinan kedua harga-harga barang menjadi naik. Dari hasil simulasi percobaan yang dilakukan menunjukkan bahwa kebijakan redenominasi tanpa mempertimbangkan kondisi perekonomian tidak memiliki pengaruh yang signifikan terhadap harga jual. Sebelum redenominasi dilakukan, rataan harga jual yang terjadi dari seluruh kelompok perlakuan sebesar Rp7.498,2 sementara setelah dilakukan redenominasi rataan harga jual menjadi Rp7.529 atau setara Rp7.529, hal ini dapat dilihat pada Grafik 1 di bawah ini. Walaupun tidak terlalu jauh berbeda perbedaannya namun ada kecenderungan setelah diterapkan redenominasi harga jual sedikit meningkat. Akan tetapi bagi komoditas yang memiliki sifat permintaan yang elastis terhadap harga, seperti mobil, setelah diterapkannya redenominasi harga jualnya akan mengalami penurunan (Astrini, 2014).

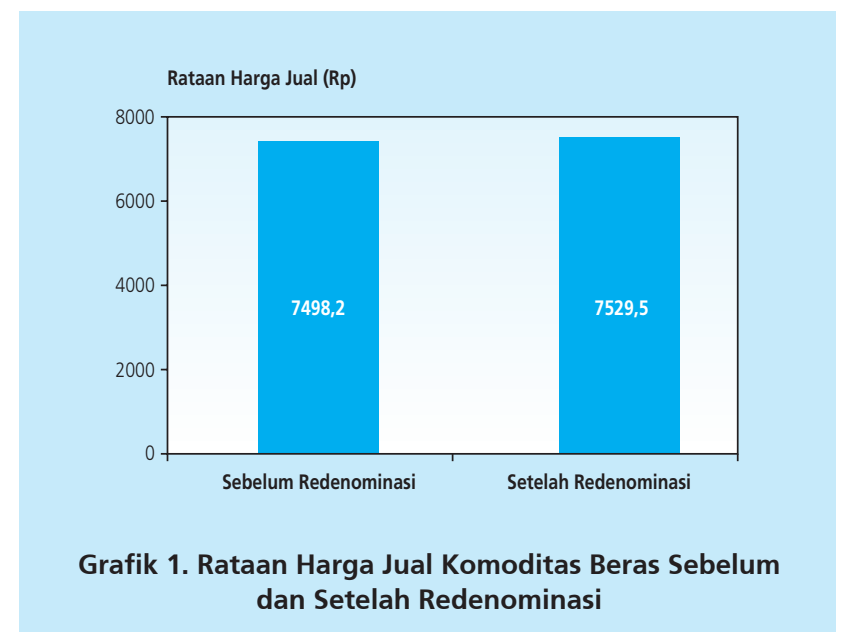

Namun demikian perlu untuk melihat perbedaan perubahan harga setelah redenominasi pada kondisi perekonomian yang berbeda seperti tingkat inflasi dan pertumbuhan ekonomi. Hal ini dimaksudkan untuk melihat apakah kondisi perekonomian yang berbeda dapat memberikan hasil yang berbeda pula terhadap perubahan harga akibat redenominasi. Perbedaan ini dianalisis dengan uji beda nilai tengah, dengan hasil pada Tabel 4 di bawah ini. Dari tabel tersebut terlihat bahwa redenominasi memiliki pengaruh yang beragam terhadap perubahan harga, hal ini tergantung dari kondisi perekonomian yang menyertainya.

Secara umum dapat dilihat pada tabel tersebut, dari semua kondisi perekonomian yang berbeda-beda, harga jual setelah redenominasi pada kondisi inflasi rendah, baik yang dikombinasikan dengan pertumbuhan ekonomi maupun tidak, mengalami penurunan atau perubahannya bernilai negatif. Sementara, hal sebaliknya terjadi pada kondisi inflasi tinggi dimana harga jual setelah redenominasi persentase perubahan harga jual bernilai positif atau mengalami peningkatan. 


\begin{tabular}{|c|c|c|c|c|}
\hline \multicolumn{5}{|c|}{$\begin{array}{l}\text { Tabel } 4 \text { Uji Beda Nilai Tengah Persentase Perubahan Harga Jual } \\
\text { Setelah Redenominasi pada Kondisi Perekonomian yang Berbeda-Beda }\end{array}$} \\
\hline Kondisi & $\begin{array}{c}\text { Persentase Perubahan } \\
\text { Harga Setelah } \\
\text { Redenominasi (\%) }\end{array}$ & $\begin{array}{l}\text { Ragam } \\
\left(\sigma^{2}\right)\end{array}$ & T-Value & P-Value \\
\hline $\begin{array}{l}\text { Inflasi Rendah } \\
\text { Inflasi Tinggi }\end{array}$ & $\begin{array}{r}-0.4559 \\
1.259\end{array}$ & Sama & 1.44 & $0.090^{*}$ \\
\hline $\begin{array}{l}\text { Low Growth } \\
\text { High Growth }\end{array}$ & $\begin{array}{l}0.19594 \\
0.60719\end{array}$ & Sama & 0.32 & 0.379 \\
\hline $\begin{array}{l}\text { Inflasi Rendah dan Low Growth } \\
\text { Inflasi Tinggi dan Low Growth }\end{array}$ & $\begin{array}{r}-0.5126 \\
0.9045\end{array}$ & Sama & 0.69 & 0.263 \\
\hline $\begin{array}{l}\text { Inflasi Rendah dan High Growth } \\
\text { Inflasi Tinggi dan High Growth }\end{array}$ & $\begin{array}{r}-0.3992 \\
1.6136\end{array}$ & Sama & 1.21 & 0.147 \\
\hline $\begin{array}{l}\text { Inflasi Rendah dan Low Growth } \\
\text { Inflasi Rendah dan High Growth }\end{array}$ & $\begin{array}{l}-0.5126 \\
-0.3992\end{array}$ & Sama & 0.06 & 0.478 \\
\hline $\begin{array}{l}\text { Inflasi Tinggi dan Low Growth } \\
\text { Inflasi Tinggi dan High Growth }\end{array}$ & $\begin{array}{l}0.9045 \\
1.6136\end{array}$ & Sama & 0.39 & 0.359 \\
\hline
\end{tabular}

Selanjutnya pada Tabel 4, dari uji beda nilai tengah dapat dilihat bahwa perbedaan perubahan harga jual setelah redenominasi hanya signifikan antara kondisi inflasi rendah dan inflasi tinggi. Hal tersebut ditunjukkan oleh nilai t-hitung sebesar 1,44 dengan nilai p sebesar 0,09 yang lebih kecil dari taraf nyata 10 persen. Signifikansi ini juga dapat dilihat pada Grafik 2 di bawah ini dimana pada saat kondisi inflasi rendah redenominasi cenderung menurunkan harga, sedangkan saat inflasi tinggi sebaliknya harga jual menjadi meningkat setelah redenominasi. Pada kondisi inflasi rendah rataan perubahan harga setelah redenominasi menurun sebesar 0.456 persen, sedangkan jika perekonomian sedang berada dalam kondisi inflasi tinggi, yang dicerminkan dengan peningkatan biaya (unit cost) penjual, harga jual akan meningkat sebesar 1.259 persen setelah redenominasi.

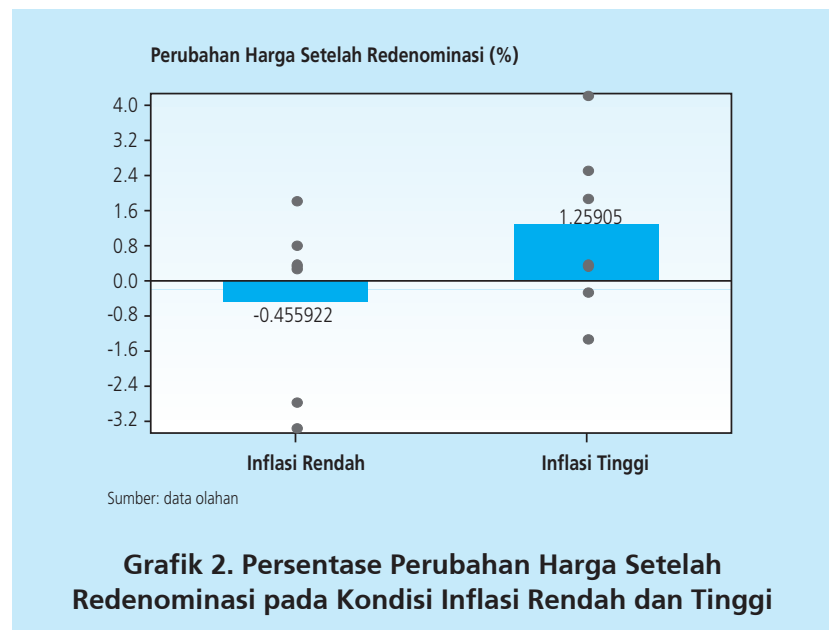


Dari hasil ini dapat dikatakan bahwa kebijakan redenominasi akan lebih baik jika diterapkan ketika perekonomian berada dalam kondisi inflasi rendah dibandingkan saat kondisi inflasi tinggi. Hasil dari percobaan ini, sejalan dengan analisis dengan pendekatan data historis 30 negara yang telah diuraikan sebelumnya dan juga teori ekonomi dimana tingkat inflasi pada saat ini akan mempengaruhi ekspektasi inflasi yang akan datang. Pada simulasi percobaan jual beli komoditas beras, adanya redenominasi dimanfaatkan oleh penjual untuk mengubah harganya menjadi lebih rendah atau tinggi daripada sebelumnya. Pada kelompok dengan perlakuan inflasi rendah (unit cost rendah) perubahan harga yang dilakukan oleh penjual cenderung menjadi lebih rendah dua sampai tiga persen dibandingkan sebelum redenominasi, meskipun ada yang menaikkan harga tapi kenaikannya sangat kecil hanya sekitar satu persen saja. Sementara itu pada kelompok dengan perlakuan inflasi tinggi (unit cost tinggi) jika diterapkan redenominasi sebagian besar penjual akan mengubah harga jualnya menjadi lebih tinggi sebesar satu sampai empat persen dibandingan sebelum redenominasi, namun tetap ada sebagian kecil penjual yang menurunkan harganya kurang dari satu persen.

Sementara itu, jika membandingkan antara kondisi pertumbuhan ekonomi tinggi (high growth) dan rendah (low growth), perubahan harga setelah redenominasi pada dua kondisi tersebut tidak memiliki perbedaan yang signifikan³. Hal ini dilihat pada Tabel 4 di atas dimana nilai p sebesar 0.379 (lebih dari taraf nyata 10 persen). Meskipun demikian, perlu dicermati disini bahwa pada pertumbuhan ekonomi rendah maupun tinggi redenominasi mata uang menyebabkan harga jual komoditas beras tetap mengalami peningkatan, masing-masing sebesar 0.195 persen dan 0.607 persen.

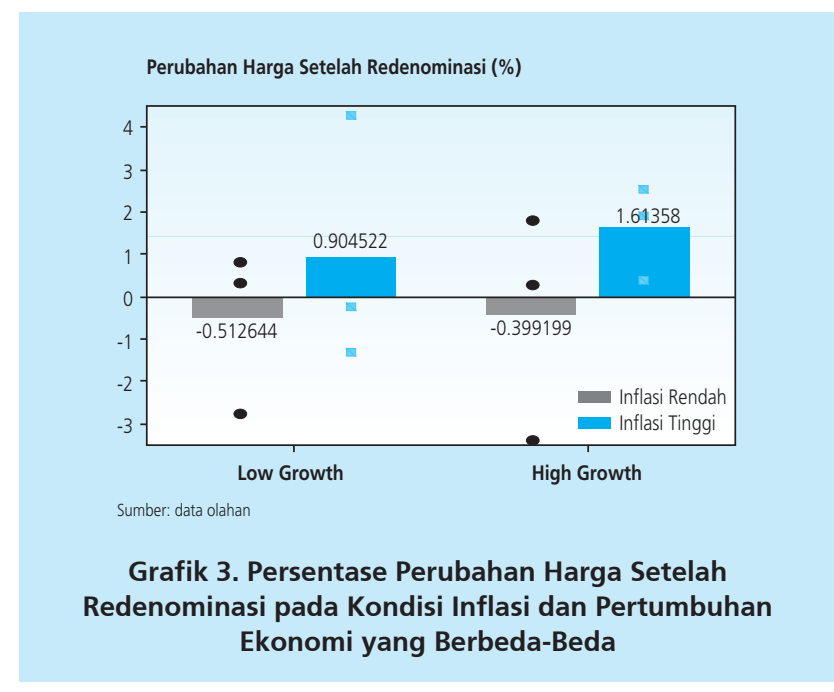

3 Pada simulasi percobaan, pertumbuhan ekonomi dicerminkan oleh jumlah penjual dan pembeli yang terlibat di pasar komoditas beras. Pada kondisi pertumbuhan ekonomi tinggi jumlah pelaku ekonomi dalam pasar lebih banyak 40 persen dibandingkan pertumbuhan ekonomi rendah. 
Peningkatan harga jual setelah redenominasi paling tinggi dialami oleh kelompok kombinasi perlakuan tingkat inflasi tinggi pada pertumbuhan ekonomi tinggi. Pada kelompok tersebut redenominasi mata uang mengakibatkan harga jual cenderung meningkat sebesar 1,61 persen. Perubahan ini jika dibandingkan dengan persentase perubahan harga jual pada kondisi inflasi rendah dengan tingkat pertumbuhan yang sama memiliki resiko kesalahan sebesar 14,7 persen ( $p$-value $=0.147$ ) atau kurang signifikan. Hal ini ditunjukkan pada Grafik 3 di atas Walaupun demikian, hal ini mengindikasikan bila redenominasi dilakukan pada saat inflasi tinggi dan pertumbuhan ekonomi tinggi yang terjadi bersamaan maka ada kecenderungan penjual untuk meningkatkan harga karena berharap adanya bias persepsi atau money illusion pada pembeli. Sehingga penjual akan menerima keuntungan yang lebih besar dengan adanya redenominasi mata uang.

Dari hasil percobaan memperlihatkan bila penjual hanya memiliki margin keuntungan yang kecil, hal ini terjadi ketika tingkat inflasi tinggi atau unit cost penjual besar, maka setelah redenominasi penjual tersebut akan meningkatkan harganya dengan harapan akan mendapatkan keuntungan yang lebih besar dari sebelumnya. Para penjual berpikir bahwa dengan menetapkan harga yang tinggi mereka akan mendapatkan keuntungan yang lebih tinggi pula. Namun sebaliknya jika penjual telah mempunyai margin keuntungan yang cukup besar, karena unit cost penjual yang relatif kecil atau inflasi rendah, maka setelah redenominasi penjual tersebut akan sedikit menurunkan harga jualnya agar barang yang dijual dapat menjadi lebih laku atau habis terjual di pasar. Hal ini dilakukan penjual untuk menghindari barang yang dijual tidak dapat terjual jika harganya tinggi. Dapat dikatakan kebijakan redenominasi memiliki pengaruh yang berbeda pada masing-masing penjual, tergantung karakteristik penjual tersebut pada saat sebelum dilakukan redenominasi, apakah berada di kelompok inflasi tinggi atau di kelompok inflasi rendah.

Hasil percobaan ini selaras dengan penelitian yang dilakukan oleh Hobijn et al. (2006) dan Gamble et al. (2002) dimana pada kasus redenominasi mata uang Euro masyarakat akan mempersepsikan bahwa harga barang menjadi lebih murah karena dihilangkannya nilai nol dari mata uang terdahulu meskipun nilai riil barang tersebut meningkat. Studi yang dilakukan oleh Shafir et al. (1997) juga memperlihatkan kesalahan yang dilakukan masyarakat dalam menghitung nilai riil dalam transaksi ekonomi, karena hanya memperhatikan nilai nominalnya saja. Studi-studi tersebut dan hasil penelitian ini membuktikan bahwa money illusion lazim terjadi pada pelaku ekonomi. Analisis uji beda nilai tengah ini dapat dijadikan sebagai tolak ukur bahwa terdapat perbedaan pengaruh redenominasi terhadap perubahan harga pada kondisi perekonomian yang berbeda, khususnya perbedaan tingkat inflasi. Sehingga dapat dilihat pada tingkat inflasi yang bagaimana redenominasi mata uang akan memberikan pengaruh ke arah yang lebih baik atau bahkan lebih buruk. 


\subsubsection{Implikasi Kebijakan Redenominasi terhadap Perubahan Jumlah Transaksi pada Sistem Pasar Posted Offer}

Apabila tidak mempertimbangkan kondisi perekonomian yang terjadi, setelah redenominasi rataan jumlah transaksi cenderung mengalami penurunan yaitu sebesar 0,33 liter dari sebelumnya. Penurunan dalam respons jumlah transaksi ini sejalan dengan respons harga jual setelah redemoninasi yang mengalami peningkatan. Hal ini sesuai dengan hukum permintaan dalam teori ekonomi dimana jika ada kenaikan harga jual maka jumlah yang diminta oleh pembeli akan mengalami penurunan (Lipsey et al, 1995). Selanjutnya, dalam kondisi perekonomian apapun kebijakan redenominasi tidak memiliki pengaruh yang berbeda terhadap respons perubahan jumlah transaksi di pasar komoditas beras. Hal ini ditunjukkan oleh Tabel 5 berikut dimana dari hasil uji beda nilai tengah persentase perubahan jumlah transaksi tidak ada yang signifikan untuk semua kelompok percobaan yang terlihat dari nilai p untuk semua perbandingan antar kelompok lebih besar dibandingkan taraf nyata 10 persen.

\begin{tabular}{|c|c|c|c|c|}
\hline \multicolumn{5}{|c|}{$\begin{array}{c}\text { Tabel } 5 \text { Uji Beda Nilai Tengah Persentase Perubahan Jumlah Transaksi Setelah } \\
\text { Redenominasi pada Kondisi Perekonomian yang Berbeda-Beda }\end{array}$} \\
\hline Kondisi & $\begin{array}{l}\text { Persentase Perubahan } \\
\text { Jumlah Transaksi Setelah } \\
\text { Redenominasi (\%) }\end{array}$ & $\begin{array}{l}\text { Ragam } \\
\left(\sigma^{2}\right)\end{array}$ & T-Value & P-Value \\
\hline Inflasi Rendah & $\begin{array}{l}-4.2328 \\
-3.3796\end{array}$ & Sama & 0.14 & 0.446 \\
\hline Low Growth & -1.8254 & & & \\
\hline High Growth & -5.787 & Sama & 0.67 & 0.260 \\
\hline Inflasi Rendah dan Low Growth & -4.7619 & & & \\
\hline Inflasi Tinggi dan Low Growth & 1.1111 & Sama & 0.51 & 0.320 \\
\hline Inflasi Rendah dan High Growth & -3.7037 & Sama & 077 & (242 \\
\hline Inflasi Tinggi dan High Growth & -7.8704 & Sama & 0.17 & 0.242 \\
\hline Inflasi Rendah dan Low Growth & -4.7619 & Sama & 0.18 & 0.435 \\
\hline Inflasi Rendah dan High Growth & -3.7037 & Sama & 0.18 & 0.435 \\
\hline Inflasi Tinggi dan Low Growth & 1.1111 & Sama & 0.79 & 0.236 \\
\hline Inflasi Tinggi dan High Growth & -7.8704 & sama & 0.19 & 0.236 \\
\hline
\end{tabular}

Perubahan jumlah transaksi setelah redenominasi cenderung mengalami penurunan lebih besar ketika pertumbuhan ekonomi tinggi dengan rataan sebesar $-5,79$ persen dibandingkan ketika pertumbuhan ekonomi rendah yang rataan penurunannya hanya $-1,83$ persen. Akan tetapi berdasarkan Tabel 5, perbedaan antara dua kondisi ini memiliki resiko kesalahan sebesar 0,26 persen atau dapat dikatakan kurang signifikan perbedaannya. Kondisi ini sejalan dengan teori yang menyatakan bahwa perubahan pada variabel nominal, dalam hal ini adalah nilai nominal mata uang dan harga, tidak mempengaruhi variabel-variabel riil (Mankiw, 2003) 


\subsubsection{Implikasi Kebijakan Redenominasi terhadap Perubahan Nilai Transaksi pada Sistem Pasar Posted Offer}

Berdasarkan hasil percobaan, kebijakan redenominasi secara umum (tanpa mempertimbangkan kondisi perekonomian) akan cenderung sedikit menurunkan nilai transaksi yang dihasilkan pada pasar komoditas beras. Sebelum redenominasi dilakukan, rataan total nilai transaksi yang terjadi dari seluruh kelompok perlakuan sebesar Rp54.675, sementara setelah dilakukan redenominasi rataan total nilai transaksi cenderung turun menjadi Rp52.483.

Sementara itu jika membandingkan kondisi perekonomian yang berbeda-beda dengan menggunakan uji beda nilai tengah terhadap persentase perubahan nilai transaksi setelah redenominasi, hasil uji menunjukkan tidak terdapat perbedaan yang nyata atau signifikan. Hal ini diperlihatkan pada Tabel 6 di atas dimana nilai p untuk semua perbandingan antar kelompok (kondisi perekonomian) lebih besar dibandingkan taraf nyata 10 persen.

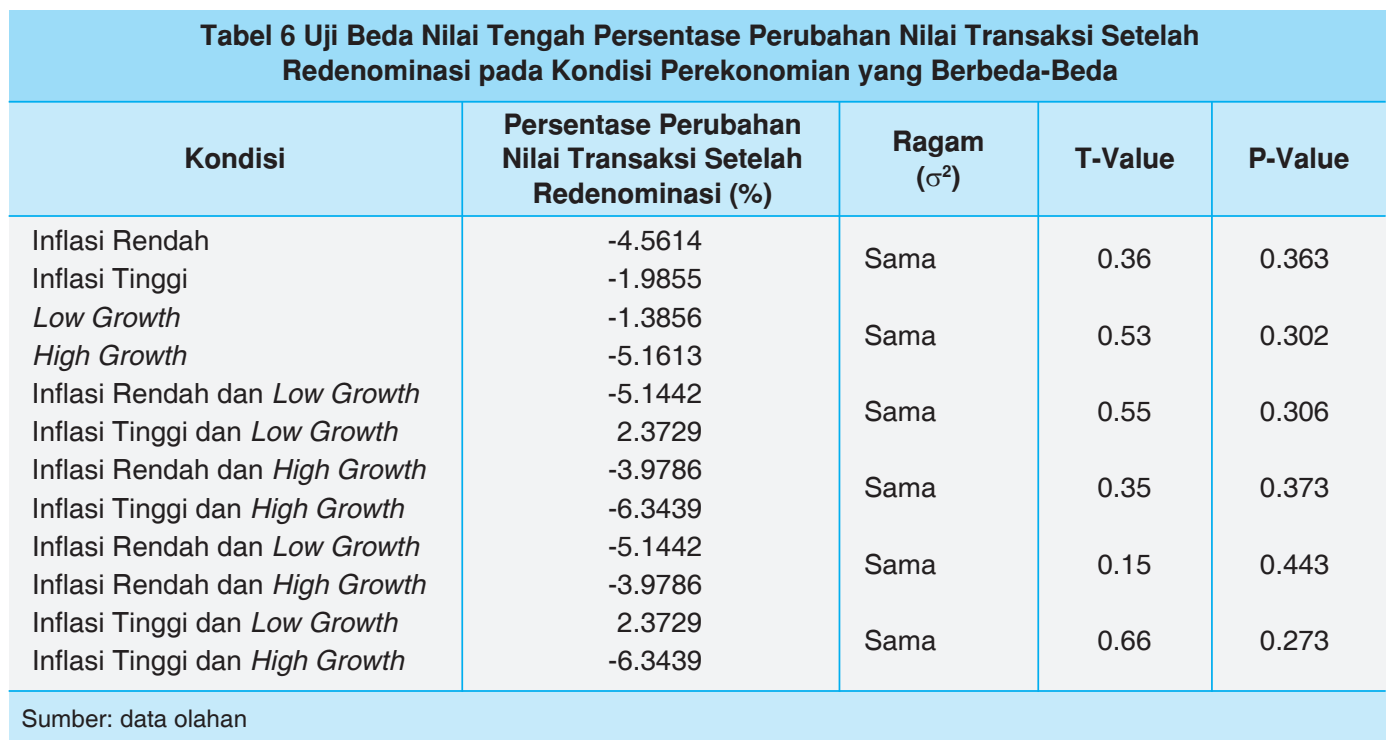

\subsection{Perspektif Masyarakat Terhadap Kebijakan Redenominasi Rupiah}

Untuk mengetahui pendapat masyarakat terhadap dampak rencana kebijakan redenominasi rupiah di Indonesia maka dilakukan survei berupa wawancara dan jajak pendapat dengan kuesioner kepada 168 orang responden di Bogor pada bulan Mei-Juni 2013.

\subsubsection{Kemampuan Pemerintah Mengendalikan Inflasi Setelah Redenominasi}

Berdasarkan hasil simulasi percobaan ekonomi yang telah dilakukan, terdapat kecenderungan bahwa harga-harga barang akan naik setelah redenominasi. Data hasil survei 
perspektif masyarakat menunjukkan hal yang serupa dengan hasil percobaan yang telah diuraikan sebelumnya, terlihat bahwa sebagian besar responden atau sebanyak 53 persen responden tidak yakin pemerintah mampu mengendalikan inflasi dengan stabil setelah kebijakan redenominasi rupiah dilakukan. Responden memiliki berbagai macam alasan, kebanyakan responden percaya bahwa setelah redenominasi dilakukan, harga-harga khususnya kebutuhan pokok akan bergerak naik. Hal ini didasarkan pada pengalaman dimana ketika ada guncangan dalam perekonomian atau peristiwa-peristiwa besar seperti hari raya keagamaan, bencana, dll harga akan cenderung naik. Kebijakan redenominasi ini juga dapat dikatakan sebagai peristiwa besar yang mengubah perilaku masyarakat terutama dalam hal transaksi jual beli. Namun demikian sebanyak 32 persen responden masih percaya jika pemerintah dapat mengendalikan inflasi setelah redenominasi, dan sisanya sebanyak 15 persen menjawab tidak tahu. Hasil survei tersebut dapat dilihat pada grafik di bawah ini.

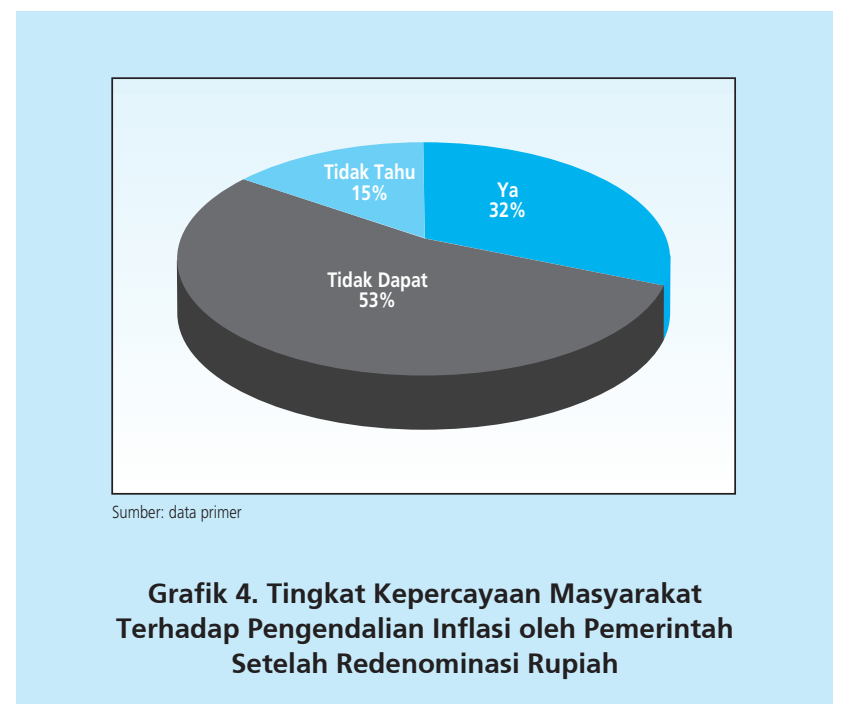

Hasil survei ini memperlihatkan bahwa ekspektasi inflasi setelah redenominasi cukup tinggi. Menurut Dornbuschet al. (2004) hanya kebijakan yang kredibel yang dapat mengubah ekspektasi inflasi menjadi sesuai dengan apa yang ditargetkan oleh pemerintah. Bagi responden yang tidak percaya terhadap pemerintah dalam hal mengendalikan inflasi setelah redenominasi beralasan karena saat ini kondisi perekonomian Indonesia belum siap untuk menghadapi kebijakan redenominasi seperti kurangnya sosialisasi dan edukasi terkait kebijakan ini serta ketiadaaan pengenalan mata uang baru kepada masyarakat. Selain itu ketidakpastian kebijakan redenominasi juga akan memberikan dampak psikologis terutama rendahnya kepercayaan terhadap pemerintah dalam hal perbaikan perekonomian. Sedangkan responden yang percaya pemerintah dapat mengendalikan inflasi setelah redenominasi berpendapat bahwa redenominasi 
rupiah tidak akan berpengaruh secara signifikan terhadap perekonomian Indonesia salah satunya adalah tingkat inflasi. Menurut mereka tingkat inflasi yang dapat dikendalikan oleh pemerintah tidak memiliki kaitan dengan kebijakan redenominasi. Sementara untuk responden yang menjawab tidak tahu, sebagian besar responden belum mengetahui rencana kebijakan redenominasi rupiah.

\subsubsection{Perubahan Pola Konsumsi Setelah Redenominasi}

Adanya kekhawatiran akan tingginya inflasi setelah kebijakan redenominasi dilaksanakan, tentunya akan berdampak kepada perubahan pola konsumsi di masyarakat misalnya akan membeli aset riil lebih banyak daripada sebelumnya dengan harapan nilai kekayaan yang dimiliki tidak turun akibat inflasi. Namun demikian, dari survei kepada 168 responden terungkap hanya sekitar 38,10 persen responden yang berpendapat lebih baik membeli aset riil setelah redenominasi dilakukan seperti yang diperlihatkan pada Grafik 5 di bawah ini. Sementara mayoritas responden sebanyak 59,52 persen cenderung memilih untuk tidak mengubah pola konsumsi mereka, hal ini dikarenakan redenominasi hanya mengubah penulisan nominal mata uang saja sehingga harga-harga barang tidak akan berubah secara signifikan. Banyak responden yang telah mengerti bahwa redenominasi tidak akan mengubah nilai riil barang, uang, kekayaan, serta daya beli seseorang. Selain itu mereka juga berpendapat bahwa tidak ada pengaruh antara kebijakan redenominasi dan perubahan tingkat inflasi.

Beberapa responden yang memilih untuk lebih banyak membeli aset riil setelah redenominasi menyatakan bahwa harga aset riil seperti emas secara psikologis akan terlihat lebih murah. Selain itu aset riil juga akan mengalami kenaikan nilai di masa mendatang, sehingga mereka merasa lebih aman untuk menyimpan kekayaannya ke dalam bentuk aset riil. Sedangkan responden yang memilih untuk lebih banyak membeli barang konsumsi setelah redenominasi diterapkan sebanyak 2,38 persen, mereka menyatakan bahwa harga-harga barang akan menjadi lebih murah sehingga tingkat konsumsinya akan meningkat. Bagi responden yang lebih banyak membeli barang konsumsi menganggap redenominasi akan mengurangi nilai uang sehingga uang yang dipegang lebih baik dibelanjakan untuk barang konsumsi daripada disimpan. Berdasarkan survei ini dapat dilihat sebagian besar responden tidak terpengaruh oleh money illusion dari redenominasi, hanya 2,38 persen responden yang tidak bebas dari pengaruh money illusion. 


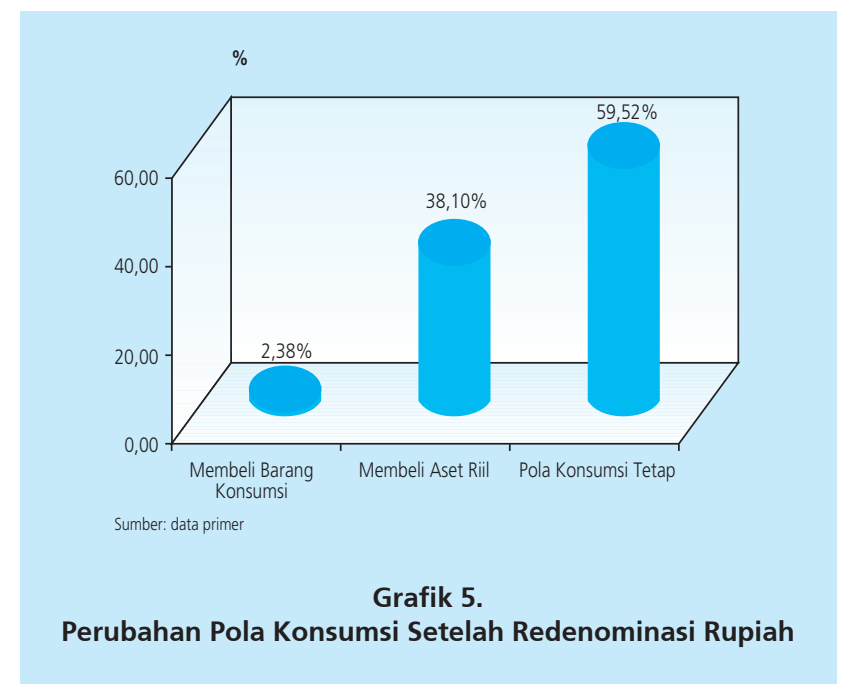

\subsubsection{Penguatan Nilai Tukar Rupiah Setelah Redenominasi}

Kebijakan redenominasi dengan menghilangkan tiga angka nol di mata uang rupiah salah satunya bertujuan untuk memberikan dampak agar nilai mata uang rupiah akan terlihat setara bahkan lebih kuat dengan mata uang-mata uang lainnya, mengingat saat ini rupiah masih termasuk mata uang dengan nilai tukar tertinggi ketiga di dunia. Hasil wawancara kepada 168 responden terlihat bahwa 37 persen responden menjawab kebijakan redenominasi tidak akan menguatkan nilai mata uang rupiah karena pergerakan nilai tukar (apresiasi dan depresiasi) lebih banyak dipengaruhi oleh faktor-faktor lain di luar perubahan nilai nominal mata uang tersebut terutama oleh faktor neraca pembayaran. Hal ini dapat dilihat pada Grafik 6 di bawah ini.

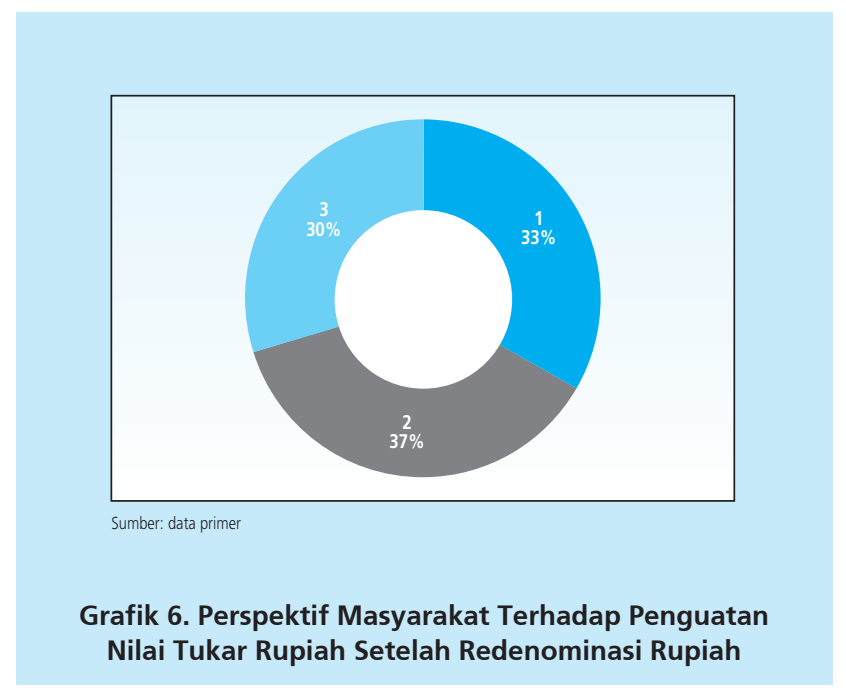


Sementara sebanyak 33 persen responden menjawab bahwa kebijakan redenominasi akan menguatkan mata uang rupiah, alasan mereka karena nilai nominal rupiah akan mendekati nilai nominal dollar AS sehingga rupiah akan terlihat lebih kuat dibandingkan sebelumnya dan akan meningkatkan kepercayaan masyarakat dalam memegang mata uang rupiah. Sedangkan 30 persen responden menjawab tidak mengetahui mengenai hubungan antara redenominasi dan nilai tukar rupiah.

\section{KESIMPULAN}

Berdasarkan beberapa hasil analisis yang telah dilakukan dengan menggunakan pendekatan data historis, percobaan ekonomi, dan wawancara serta dari pembahasan yang telah diuraikan sebelumnya terkait kebijakan redenominasi mata uang, maka penelitian ini menyimpulkan:

Jika keberhasilan dari dilaksanakannya kebijakan redenominasi diukur oleh rendahnya tingkat inflasi dan tingginya pertumbuhan ekonomi, maka keberhasilan redenominasi cenderung dapat dipengaruhi oleh kondisi perekonomian pada saat suatu negara menerapkan redenominasi mata uangnya. Negara-negara yang melakukan redenominasi ketika tingkat inflasinya rendah $(<10 \%)$, maka tingkat inflasi pada satu tahun setelahnya akan lebih rendah daripada negaranegara yang melakukan redenominasi ketika tingkat inflasinya sedang tinggi ( $\geq 10 \%)$. Sementara itu, pertumbuhan ekonomi setelah redenominasi dapat meningkat lebih tinggi jika pada saat redenominasi dilakukan kondisi perekonomian sedang mengalami pertumbuhan yang tinggi pula.

Berdasarkan hasil percobaan ekonomi transaksi jual beli beras pada sistem pasar postedoffer, naik atau turunnya harga jual setelah redenominasi signifikan dipengaruhi oleh kondisi tingkat inflasi yang menyertainya. Pada saat tingkat inflasi tinggi kebijakan redenominasi dapat meningkatkan harga jual, sebaliknya ketika tingkat inflasi rendah redenominasi menurunkan harga jual. Sementara itu, pertumbuhan ekonomi tidak mempengaruhi perubahan harga jual setelah redenominasi. Dari hasil percobaan tersebut juga terungkap pada kondisi perekonomian yang berbeda-beda, kebijakan redenominasi tidak signifikan mempengaruhi perubahan jumlah transaksi dan nilai total transaksi yang terjadi di pasar. Namun jika tidak memperhatikan kondisi perekonomian, secara umum redenominasi menyebabkan kenaikan harga jual, penurunan jumlah transaksi, dan penurunan nilai transaksi. Dari hasil survei terungkap sebagian besar responden tidak percaya pemerintah dapat mengendalikan inflasi setelah redenominasi dilakukan. Redenominasi juga tidak akan mempengaruhi pola konsumsi masyarakat dan masyarakat juga tidak terlalu meyakini redenominasi dapat memperkuat nilai tukar rupiah

Dilihat dari hasil penelitian, hal yang penting dalam pelaksanaan kebijakan redenominasi mata uang adalah kondisi perekonomian pada saat dilaksanakannya kebijakan tersebut. Akan lebih baik jika redenominasi diterapkan ketika perekonomian berada dalam kondisi yang baik 
dan stabil, seperti tingkat inflasi yang rendah dan pertumbuhan ekonomi yang tinggi. Sosialisasi kebijakan redenominasi kepada masyarakat perlu dilakukan sebelumnya dengan intensif dan konsisten untuk memberikan informasi yang jelas kepada publik terkait kebijakan tersebut.

Selain itu penulis menyarankan perlu dilakukan penelitian lebih lanjut yang difokuskan mengenai dampak dari redenominasi mata uang secara langsung terhadap kondisi perekonomian. Selain itu, perlu dilakukan penelitian lanjutan dengan percobaan ekonomi serupa untuk sistem transaksi selain posted-offer yaitu sistem desentralisasi dan double auction. Penelitian lanjutan sebaiknya menggunakan pelaku percobaan yang berbeda untuk setiap ulangan dan setiap perlakuan, sehingga pelaku percobaan tidak memiliki pengalaman dari ulangan sebelumnya. Hal ini dimaksudkan agar mendapatkan hasil percobaan yang relatif lebih baik. Penelitian selanjutnya diharapkan memperluas cakupan pengaruh respons dan menambah faktor-faktor lain, sehingga dapat memberikan gambaran yang lebih nyata terkait dampak kebijakan redenominasi terhadap perekonomian. Simulasi percobaan akan lebih baik jika menggunakan komputer yang saling terkoneksi antar pelaku percobaan, agar meminimumkan pengaruh faktor lain diluar perlakuan. 


\section{DAFTAR PUSTAKA}

Amir, A. "Redenominasi Rupiah dan Sistim Keuangan", Jurnal Paradigma Ekonomika. Vol. 1, No. 4 Oktober 2011.

Astrini, Danti. "Kajian Dampak Redenominasi terhadap Perekonomian dengan Metode Percobaan Ekonomi", Tesis, Sekolah Pascasarjana, Institut Pertanian Bogor, 2014.

Blanchard, O, (2006), Macroeconomics Fourth Edition, Pearson Prentice Hall.

Dornbusch, R, Fischer S, dan Startz R, (2004), Macroeconomics Ninth Edition, McGraw Hill, New York.

Gamble, A, Garling T, Charlton J, \& Ranyard R. "Euro Illusion", European Psychologist 7, 2002, 4: 302-31.

Hobijn, Bart, F. Ravena, dan A. Tambalotti. "Menu Costs at Work: Restaurant Prices and the Introduction of the Euro", The Quarterly Journal of Economics, 2006, 121 (3): 1103-1131.

Iona, D. "The National Currency Re-denomination Experience in Several Countries: A Comparative Analysis", International Multidisciplinary Symposium Universitaria Simpro, 2005.

Juanda, B. "Percobaan Ekonomi untuk Mengkaji Pengaruh Informasi Serta Jumlah Penjual dan Pembeli dalam Transaksi Pasar", November 2000, Jurnal Ekonomi Vol. 7, III, Universitas Borobudur.

. "Ekonomi Eksperimental untuk Pengembangan Teori Ekonomi dan Pengkajian Suatu Kebijakan", Di dalam: Orasi Guru Besar IPB, 25 September 2010.

"Experimental Economics in Indonesia: Lesson Learned and Best Practices",

Di dalam: Workshop on Experimental Economics, Bogor 6 September 2012.

Juanda, B, N. Fitri, F. Fardilah, dan M.P.D. Manik, (2011),"Analisis Perbandingan Dampak Kebijakan Menyelamatkan Bank Century dengan kebijakan Menutup Bank Century dengan Metode Eksperimen", Departemen Ilmu Ekonomi, FEM-IPB, Bogor.

Kesumajaya, I.W.W. "Redenominasi Mata Uang Rupiah Merupakan Bagian dari Tugas Bank Indonesia untuk Mengatur dan Menjaga Kelancaran Sistim Pembayaran di Indonesia" ,GaneC Swara Vol. 5 No.1, Pebruari 2011.

Lianto, J dan Ronald Suryaputra. "The Impact of Redenomination in Indonesia from Indonesian Citizens' Perspective", Procedia - Social and Behavioral Sciences 40 (2012): 1 - 6.

Lipsey, R.G, P.N Courant, D.D Purvis, dan P.O Steiner,(1995),Pengantar Mikroekonomi Jilid Satu Edisi Kesepuluh. Binarupa Aksara. Jakarta. Terjemahan dari: Economics $10^{\text {th }}$ ed. 
Mankiw, N.G,(2003),Teori Makroekonomi Edisi Kelima. Erlangga. Jakarta. Terjemahan dari: Macroeconomics $5^{\text {th }}$ Edition.

Matjik, A.A, dan I.M. Sumertajaya, (2002), Perancangan Percobaan dengan Aplikasi SAS dan MINITAB Jilid I Edisi Kedua. IPB Press. Bogor.

Marques, J.F dan Dehaene, S. "Developing Intuition for Price in Euros", Journal of Experimental Psychology 10, 2004, 3: 148-155.

Mehdi, S dan Motiee Reza. "An investigating Zeros Elimination of the National Currency and Its Effect on National Economy (Case study in Iran)", European Journal of Experimental Biology, 2012, 2 (4):1137-1143.

Mosley, L. "Dropping Zeros, Gaining Credibility? Currency Redenomination in Developing Nations", 2005 Annual Meeting of The American Political Science Association, Washington DC.

Shafir, E, P. Diamond, dan A. Tversky. "Money Illusion", The Quarterly Journal of Economics (May 1997) 112 (2): 341-374.

Suhendra, E dan S.W. Handayani. "Impacts of Redenomiantion on Economics Indicators", International Conference on Eurasian Economies, 2012.

The World Bank. "World Development Indicators 2012", 2012.

Wibowo. B. "Ilusi Nilai Uang Redenominasi", Harian Bisnis Kontan, Kamis 21 Februari 2013. 